ACTA AGROBOTANICA

Vol. 59 z. 22006

s. 5158

\title{
Antifungal activity of saponins originated from Medicago hybrida against some ornamental plant pathogens
}

\section{ALICJA SANIEWSKA ${ }^{1}$, ANNA JARECKA ${ }^{1}$, ZBIGNIEW BIAEY $^{2}$, MARIAN JURZYSTA ${ }^{2}$}

\author{
${ }^{1}$ Research Institute of Pomology and Floriculture, Pomologiczna 18, 96100 Skierniewice, \\ Poland, e mail: asaniew@insad.pl \\ ${ }^{2}$ Department of Biochemistry and Plant Quality, Institute of Soil Science and Plant Cultivation, \\ Czartoryskich 8, 24100 Puławy, Poland, e mail: mjurzyst@iung.pulawy.pl
}

(Received: 24.04.2006)

\section{$\mathrm{S}$ u m m a r y}

Antifungal activity of total saponins originated from roots of Medicago hybri$d a$ (Pourret) Trautv. were evaluated in vitro against six pathogenic fungi and eight individual major saponin glycosides were tested against one of the most susceptible fungi. The total saponins showed fungitoxic effect at all investigated concentrations $(0.01 \%, 0.05 \%$ and $0.1 \%)$ but their potency was different for individual fungi. The highest saponin concentration $(0.1 \%)$ was the most effective and the inhibition of Fusarium oxysporum f. sp. callistephi, Botrytis cinerea, Botrytis tulipae, Phoma narcissi, Fusarium oxysporum f. sp. narcissi was 84.4\%, 69.9\%, 68.6\%, 57.2\%, 55.0\%, respectively. While Fusarium oxysporum Schlecht., a pathogen of Muscari armeniacum, was inhibited by $9.5 \%$ only. Eight major saponin glycosides isolated from the total saponins of $M$. hybrida roots were tested against the mycelium growth of Botrytis tulipae. The mycelium growth of the pathogen was greatly inhibited by hederagenin 3- $O$ - $\beta$-D-glucopyranoside and medicagenic acid 3- $O-\beta$-D-glucopyranoside. Medicagenic acid 3-O- $\beta$-D-glucuronopyranosyl-28- $O-\beta$-D-glucopyranoside and oleanolic acid 3- $O$-[ $\beta$-D-glucuronopyranosyl $(1 \rightarrow 2)$ - $\alpha$-L-galactopyranosyl]-28- $O$ - $\beta$-D-glucopyranoside showed low fungitoxic activity. Medicagenic acid 3-O-a-D-glucopyranosyl$28-O$ - $\beta$-D-glucopyranoside, hederagenin 3- $O$ - $[\alpha$-L-rhamnopyranosyl $(1 \rightarrow 2)-\beta$-D-glucopyranosyl $(1 \rightarrow 2)$ - $\beta$-D-glucopyranosyl]- $28-O-\beta$-D-glucopyranoside and hederagenin 3-O- $\alpha$-D-glucuronopyranosyl-28- $O-\beta$-D-glucopyranoside did not limit or only slightly inhibited growth of the tested pathogen. While $2 \beta, 3 \beta$-dihydroxyolean- 12 ene-23-al-28-oic acid 3- $O$ - $\beta$-D-glucuronopyranosyl-28- $O$ - $\beta$-D-glucopyranoside slightly stimulated mycelium growth of $B$. tulipae. 


\section{INTRODUCTION}

It is commonly known that use of some fungicides can create dangers to health and to our natural environment. Therefore, during the last decade, more and more studies have been carried out on the possibility of using natural plant-based substances, which would be less toxic than those synthetic chemicals. A considerable number of world publications have drawn attention to the possibility of using saponins, as natural fungicides (H o s te t t m a n $\mathrm{n}$ and M a r s to n, 1955; O le s z e k, 1996). Searching for new plant originated substances, a couple of years ago, we screened twenty nine Medicago species and found that a few of them were very rich in fungicidal saponins (J u r z y s t a and W a l e r, 1996; J u r z y s t a and B i a ł y, 1999). Consistently, chemical structure and fungicidal activity of saponins of species such as M. sativa (L e v y et al. 1989, B i a ł y et al. 1999; M a r t y n i u k et al. 1996; S aniewska et al. 2001;2003), M. arabica (Martyniuk et al. 2004; B i ały et al. 2004; M a r t y n i u k et al. 2004; S a n i e w s k a et al. 2005), M. arborea ( $\mathrm{T}$ a $\mathrm{v}$ a et al. 2005) and M. hybrida (B i a $ł$ y et al. 2006) have been studied.

Recently, we isolated from roots of Medicago hybrida fourteen triterpene saponins and established their structures (B i a 1 y et al. 2006), but did not study their biological activities. In the present study, antifungal activity of total saponins from roots of this species was evaluated in vitro against six fungi and eight individual major saponin glycosides were tested against Botrytis tulipae, one of the most susceptible fungus.

\section{MATERIALS AND METHODS}

\section{Total saponins and saponin glycosides}

Total saponins and their individual glycosides were isolated from roots of $M$. hybrida (Pourret.) Trautv. according to the procedure described by $\mathrm{B}$ i a $1 \mathrm{y}$ et al. (2006). Shortly, the ground plant material was defatted with chloroform, and then extracted with methanol under reflux. After removal of alcohol, the residue was dissolved in a small volume of water and the solution was placed on a LiChroprep RP 18 column. The column was washed with water and with diluted methanol until colourless solution was obtained. Total saponins were eluted with methanol and dried. Then the obtained total saponins were fractionated on a silica gel column by eluting with $n$-butanol saturated with water, and individual saponin glycosides were separated from the fractions by means of reversed-phase chromatography on LiChroprep RP-18 columns eluting with aqueous methanol solutions. Saponin structures were established on the basis of hydrolysis and spectral evidence, including IR, optical rotations, NMR and FAB-MS analyses (B i a $ł$ y et al. 2006).

The total saponins and the following saponin glycosides (Fig. 1) were studied for their antifungal activity:

1. Hederagenin 3-O- $\beta$-D-glucopyranoside

2. Medicagenic acid 3-O- $\beta$-D-glucopyranoside

3. Medicagenic acid 3-O- $\beta$-D-glucopyranosyl-28-O- $\beta$-D-glucopyranoside 
4. Hederagenin 3- $O$ - $\alpha$-L-rhamnopyranosyl $(1 \rightarrow 2)$ - $\beta$-D-glucopyranosyl $(1 \rightarrow 2)$ $\beta$ - D-glucopyranosyl]-28- $O$ - $\beta$-D-glucopyranoside

5. Hederagenin 3-O- $\beta$-D-glucuronopyranosyl-28- $O$ - $\beta$-D-glucopyranoside

6. $2 \beta, 3 \beta$-dihydroxyolean-12ene-23-al-28-oic acid 3-O- $\beta$-D-glucuronopyranosyl- 28- $O$ - $\beta$-D-glucopyranoside

7. Medicagenic acid 3-O- $\beta$-D-glucuronopyranosyl-28- $O-\beta$-D- glucopyranoside

8. Oleanolic acid 3- $O$-[ $\beta$-D-glucuronopyranosyl $(1 \rightarrow 2)-\beta$-D-galactopyranosyl]$28-O-\beta$-D-glucopyranoside
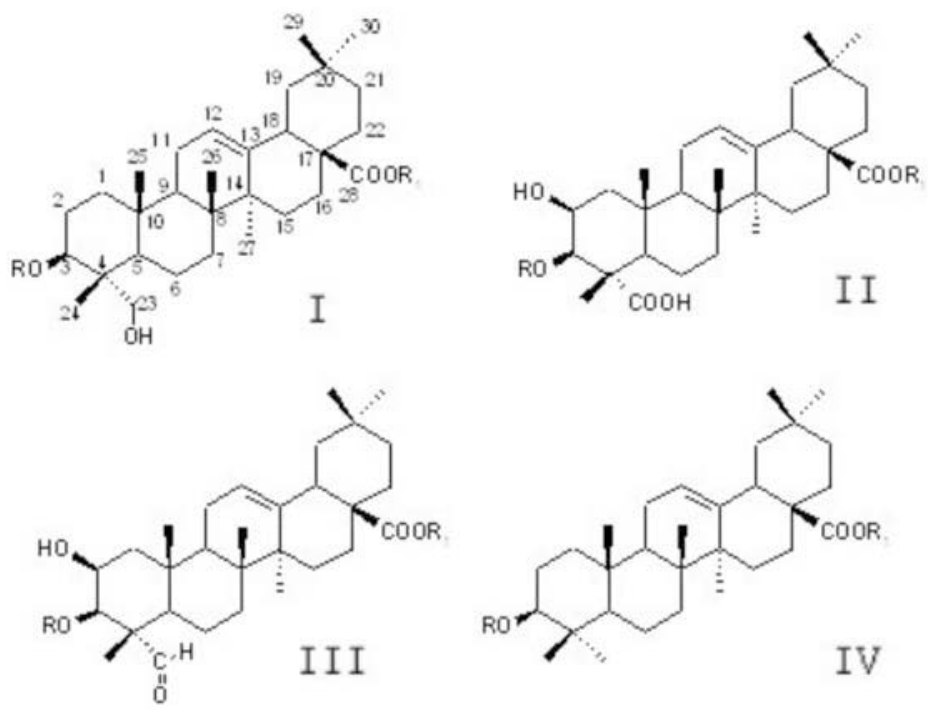

\begin{tabular}{llll}
\hline Saponins & Aglicone & $\mathrm{R}$ & $\mathrm{R}_{1}$ \\
\hline $\mathbf{1}$ & I & $\beta$-D-Glc & $\mathrm{H}$ \\
$\mathbf{2}$ & II & $\beta$-D-Glc & $\mathrm{H}$ \\
$\mathbf{3}$ & II & $\beta$-D-Glc & $\beta$-D-Glc \\
$\mathbf{4}$ & I & $\beta$-L-Rha( $1 \rightarrow 2)-\beta$-D-Glc $(1 \rightarrow 2)-\beta-\mathrm{D}-\mathrm{Glc}$ & $\beta$-D-Glc \\
$\mathbf{5}$ & I & $\beta$-D-GlcA & $\beta$-D-Glc \\
$\mathbf{6}$ & III & $\beta$-D-GlcA & $\beta$-D-Glc \\
$\mathbf{7}$ & II & $\beta$-D-GlcA & $\beta$-D-Glc \\
$\mathbf{8}$ & IV & $\beta$-D-Gal $(1 \rightarrow 2)-\beta$-D-GlcA & $\beta$-D-Glc \\
\hline
\end{tabular}

Fig. 1. Structure of saponins $1 \mathbf{8}$ (I, hederagenin; II, medicagenic acid; III, $2 \beta, 3 \beta$ dihydroxyole an 12 ene 23 al 28 oic acid; IV, oleanolic acid). 
Table 1.

Inhibitory effect of total saponins originated from roots of Medicago hybrida $\mathrm{L}$. on the mycelial growth of some pathogenic fungi.

\begin{tabular}{|l|c|c|c|c|}
\hline \multirow{2}{*}{ Pathogenic fungi } & \multirow{2}{*}{$\begin{array}{c}\text { Days of } \\
\text { incubation }\end{array}$} & \multicolumn{3}{|c}{$\begin{array}{c}\text { Inhibition of mycelium growth (\%) at } \\
\text { a saponin concentration of }\end{array}$} \\
\cline { 3 - 5 } & & $0.01 \%$ & $0.05 \%$ & $0.1 \%$ \\
\hline Botrytis cinerea & 4 & $76.9 \mathrm{ab}$ & $80.0 \mathrm{a}$ & $69.9 \mathrm{~b}$ \\
Botrytis tulipae & 5 & $77.1 \mathrm{a}$ & $80.8 \mathrm{a}$ & $68.6 \mathrm{a}$ \\
Fusarium oxysporum f. sp. callistephi & 7 & $36.6 \mathrm{c}$ & $59.6 \mathrm{~b}$ & $84.4 \mathrm{a}$ \\
Fusarium oxysporum f. sp. narcissi & 7 & $39.4 \mathrm{c}$ & $48.7 \mathrm{~b}$ & $55.0 \mathrm{a}$ \\
Fusarium oxysporum , a pathogen of & 7 & $5.5 \mathrm{~b}$ & $11.8 \mathrm{a}$ & $9.5 \mathrm{ab}$ \\
$\begin{array}{l}\text { Muscari armeniacum } \\
\text { Phoma narcissi }\end{array}$ & 5 & $33.0 \mathrm{c}$ & $52.9 \mathrm{~b}$ & $57.2 \mathrm{a}$ \\
\hline
\end{tabular}

Means in row followed by the same letters are not significantly different at $\mathrm{P}=0.05$ according to Duncan's test.

Table 2.

The effect of individual saponins, indicated in Materials and Methods as numbers $3 \mathbf{8}$, on the mycelium growth of Botrytis tulipae after six days of incubation (\% of control).

\begin{tabular}{|l|c|c|c|c|c|}
\hline snin 3 & Saponin 4 & Saponin 5 & Saponin 6 & Saponin 7 & Saponin 8 \\
\hline 1.0 & +41.5 & 0.0 & +9.0 & -5.7 & -8.7 \\
1.0 & -30.6 & -2.4 & +28.0 & -11.3 & -15.0 \\
1.0 & +35.7 & -22.0 & -44.4 & -0.8 & -10.9 \\
1.0 & +22.3 & -26.8 & -49.0 & -22.8 & -10.7 \\
\hline
\end{tabular}

"+” stimulatory effect, " ” inhibitory effect

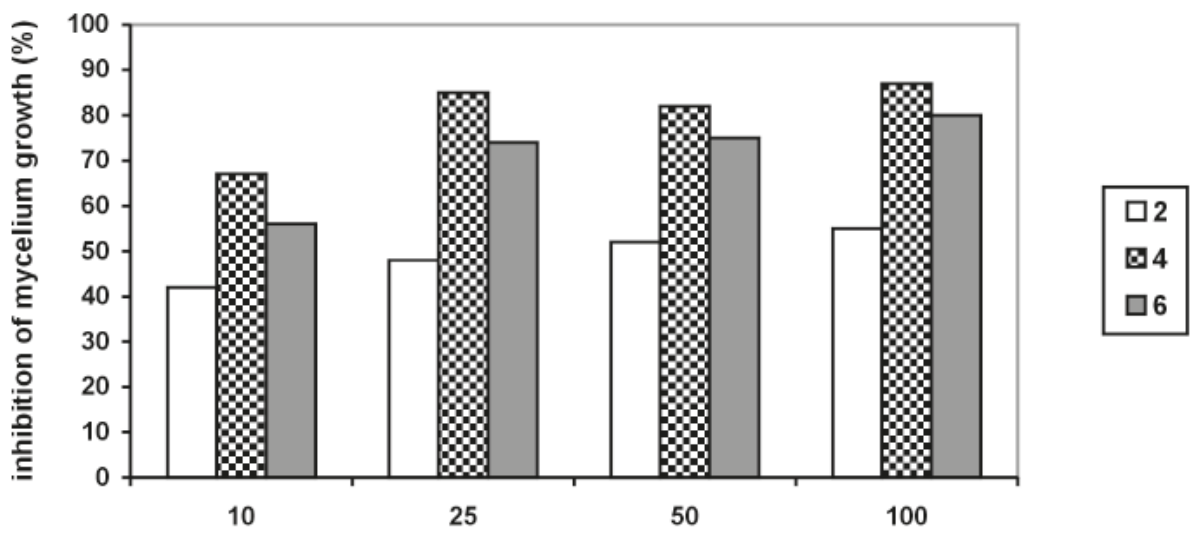

Concentration in $\mu \mathrm{g} \cdot \mathrm{cm}^{-3}$

Fig. 2. Inhibitory effect of hederagenin $3 O \beta \mathrm{D}$ glucopyranoside (1) in different concentrations on in vitro mycelium growth of Botrytis tulipae after 2, 4 and 6 days of incubation. 


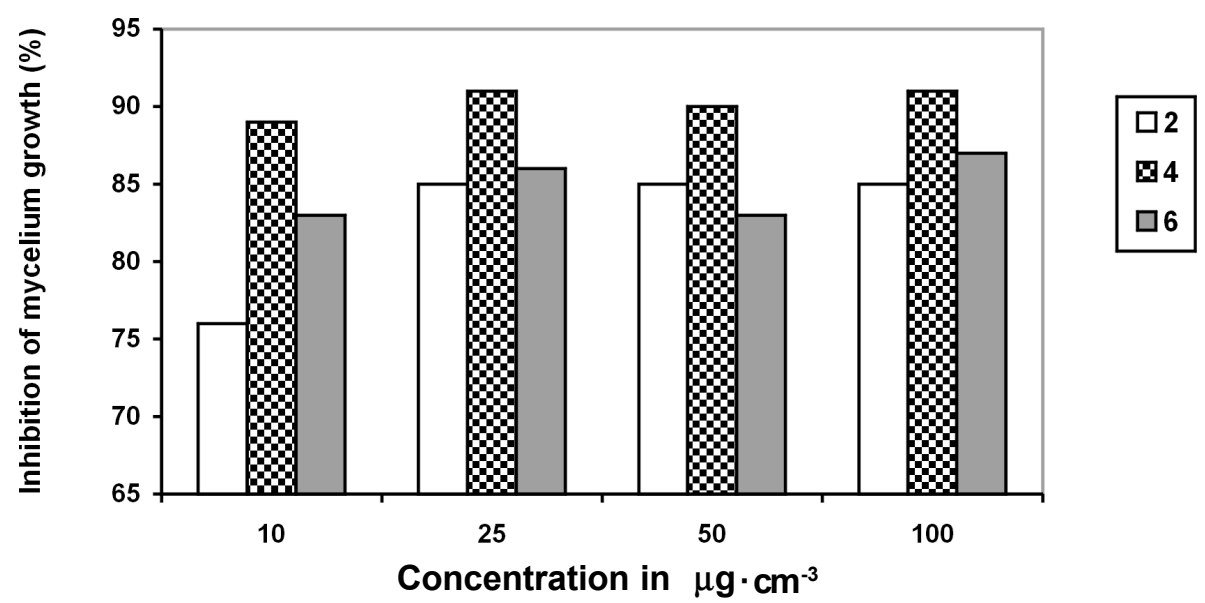

Fig. 3. Inhibitory effect of medicagenic acid $3 O \beta \mathrm{D}$ glucopyranoside (2) in different concentra tion on in vitro mycelium growth of Botrytis tulipae after 2, 4 and 6 days of incubation.

\section{In vitro growth of some pathogenic fungi in the presence of saponins}

Botrytis cinerea Pers. [Botryotinia fuckeliana (de Bary) Whetzel], Botrytis tulipae (Lib.) Lind, Phoma narcissi Aderh. [syn. Stagonospora curtissi (Berk.) Sacc.], Fusarium oxysporum Schlecht. f. sp. callistephi (Beach.) Snyd. et Hans., Fusarium oxysporum Schlecht. f. sp. narcissi Snyd. et Hans., and Fusarium oxysporum Schlecht., a pathogen of Muscari armeniacumm, were used for investigation. The total amount of saponins originated from roots of Medicago hybrida at final concentrations of $0.01 \% ; 0.05 \%$ and $0.1 \%$ were previously dissolved in $5 \mathrm{~cm}^{3}$ distilled and sterilized water and added to potato-dextrose-agar (PDA-Merck) after sterilization at a temperature of about $50^{\circ} \mathrm{C}$. The single saponins isolated from roots of $M$. hybrida at final concentrations of $10,25,50$ and $100 \mu \mathrm{g} \cdot \mathrm{cm}^{-3}$ were dissolved in $3 \mathrm{~cm}^{3}$ of $75 \%$ methanol and added to $100 \mathrm{~cm}^{3}$ of PDA after sterilization. Five mm diameter plugs taken from 7-day-old culture of tested fungi, were placed in the middle of $90 \mathrm{~mm}$ Petri dishes containing PDA medium supplemented with the tested compounds and control without saponins. The plates were incubated at $25^{\circ} \mathrm{C}$ in darkness. The diameter of colonies was measured within 4, 5 or 7 days-incubation depending on the fungus being tested. Five dishes were used for each treatment and the experiment was repeated twice. To analyze the differences between mean values, Duncan's test was used, with a significance level of $\alpha=0.05$.

\section{RESULTS AND DISCUSSION}

The total saponins at concentrations of $0.01 \%, 0.05 \%$ and $0.1 \%$ showed strong fungitoxic effect against all of the investigated fungi (Table 1). However, there were variable effects on the growth of those fungi. Saponins greatly inhibited the growth of Fusarium oxysporum f. sp. callistephi, Botrytis cinerea, Botrytis tulipae, Phoma narcissi, Fusarium oxysporum f. sp. narcissi and linear growth of the mycelium of these 
fungi, treated with $0.1 \%$ solution of saponins, was inhibited by $84.4 \%, 69.9 \%, 68.6 \%$, $57.2 \%, 55.0 \%$, respectively, in relation to the control culture. While, linear growth of the mycelium of Fusarium oxysporum Schlecht., a pathogen of Muscari armeniacum was inhibited only by $9.5 \%$.

It should be mentioned that different concentrations of saponins similarly inhibited mycelium growth of Botrytis cinerea and Botrytis tulipae, or higher concentration slightly less inhibited the mycelium growth of $B$. cinerea (Table 1). It is suggested that lower concentrations of saponins were sufficient to block all active places (receptors?) in mycelium hyphae. The mechanism of inhibitory effect of saponins on mycelium growth is unknown. It is also possible that higher concentrations of saponins may interact with other endogenous compound(s) of mycelium and finally the inhibitory effect on mycelium growth is slightly decreased.

According to our knowledge, saponins of M. hybrida have never been studied for fungicidal properties, although we have recently shown that saponins of this species possess an insecticidal activity as high as $M$. arabica or $M$. murex saponins ( $\mathrm{S}$ z c z e p a $\mathrm{n}$ i k et al. 2004). On the other hand it is known that both of these species are also rich in highly fungicidal saponins (M a r t y n i u k et al. 2002; S a n i e w s k a et al. 2005).

The individual saponin glycosides (Fig. 1) exerted different effects on the mycelium growth of Botrytis tulipae. Two of them: hederagenin 3-O- $\beta$-D-glucopyranoside (1) and medicagenic acid 3-O- $\beta$-D-glucopyranoside (2) had the strongest inhibitory influence against the mycelium growth of $B$. tulipae on PDA medium (Fig. 2 and 3). Hederagenin 3- $O$ - $\beta$-D-glucuronopyranosyl-28- $O$ - $\beta$-D-glucopyranoside (5), medicagenic acid 3-O- $\beta$-D-glucuronopyranosyl-28- $O$ - $\beta$-D-glucopyranoside (7) and oleanolic acid 3-O-[ $\beta$-D-glucuronopyranosyl $(1 \rightarrow 2)-\beta$-D-galactopyranosyl $]-28-O$ - $\beta$-Dglucopyranoside (8) showed low fungitoxic activity against the mycelium growth of the pathogen (Table 2). Medicagenic acid 3- $O-\beta$-D-glucopyranosyl-28- $O-\alpha$-D-glucopyranoside (3) and hederagenin 3- $O$ - $[\alpha$-L-rhamnopyranosyl $(1 \rightarrow 2)$ - $\beta$-D-glucopyra$\operatorname{nosyl}(1 \rightarrow 2)-\beta$-D-glucopyranosyl]-28- $O$ - $\beta$-D-glucopyranoside $(4)$ did not limit or stimulate the growth of the tested pathogen (Table 2 ). $2 \beta, 3 \beta$-dihydroxyolean-12ene-23al-28-oic acid 3- $O$ - $\beta$-D-glucuronopyranosyl-28- $O$ - $\beta$-D-glucopyranoside (6) slightly stimulated mycelium growth of $B$. tulipae at a low concentrations and inhibited growth at higher concentrations (Table 2). There are many examples in the literature showing that monodesmosidic saponins possessing a single sugar chain at C-3 exhibit very high biologically activities in comparison with bidesmosidic saponins which have two sugar chains. For example medicagenic acid 3- $O-\beta$-D-glucopyranoside shows large fungitoxic activity against many plant pathogens (L e v y et al. 1986; M a r t y n i u k et al. 1996, 2005; S a n i e w s k a et al. 2003). While, bidesmosidic glycosides of medicagenic acid exhibit very low activity.

It can be seen that $M$. hybrida saponins consist of both monodesmosidic and bidesmosidic glycosides (Fig. 1). Looking at the structure of these bidesmosidic glycosides, from the chemical point of view, it is easy to notice that alkaline hydrolysis of most of them could eliminate sugar chains from the ester linkage at C-28 and induce transformation of low biologically active saponins being bidesmosides into high active monodesmoside. Thus, this procedure allows the creation of highly biologically active medicagenic acid 3-O- $\beta$-D-glucopyranoside from the saponin 3. Similarly, 
bidesmosidic saponins $\mathbf{5 , 6}$ and $\mathbf{7}$ could be converted into monodesmosides: hederagenin 3-O- $\beta$-D-glucuronopyranoside, $2 \beta, 3 \beta$-dihydroxyolean-12ene-23-al-28-oic acid 3 - $O$ - $\beta$-D-glucuronopyranoside and medicagenic acid 3-O- $\beta$-D-glucuronopyranoside, respectively. Antifungal activity of these hypothetical saponins should be studied but on the basis of data in the literature these saponins are expected to be highly biologically active.

In conclusion, saponins of Medicago hybrida have been shown to possess significant antifungal activity and roots of this plant could be a rich source of natural fungicides.

\section{REFERENCES}

B i a ł y Z., J u r z y s t a M., 2000. Wpływ saponin lucerny siewnej (Medicago sativa L.) na wzrost grzyba Trichoderma viride. Progr. Plant Protec./Postępy w Ochronie Roślin, 40 (2): 706708.

B i a ł y Z., J u r z y s t a M., Me 11 a M., T a v a A., 2004. Triterpene saponins from aerial parts of Medicago arabica L. J. Agric. Food Chem. 52: 10951099.

B i a 1 y Z., J u r z y s t a M., M e 11 a M., T a v a A., 2006. Triterpene saponins from the roots of Medicago hybrida. J. Agric. Food Chem. 54: 25202526.

B i a ł y Z., J u r z y s t a M., O 1 e s z e k W., P i a c e n t e S., P i z z a C., 1999. Saponins in alfalfa (Medicago sativa L.) root and their structural elucidation. J. Agric. Food Chem. 47(8): 31853192.

H o s t e t t m a n n K., M a r s t o n A., 1995. Saponins. Cambridge University Press, pp 548.

J u r z y s t a M., B i a ł y Z., 1999. Antifungal and hemolytic activity of roots of alfalfa (Medicago app.) in relation to saponin composition. In: Modern Fungicides and Antifungal Compo unds II, H. Lyr, P.E. Russell, H. W. Dehne, H. D. Sisler; Intercept, Andover, UK, pp. 445451.

J u r z y s t a M., W a 11 e r G.R., 1996. Antifungal and hemolytic activity of aerial parts of alfalfa (Medicago) species in relation to saponin composition. In: Saponin used in traditional and modern medicine. Eds. G.R Weller.; K. Yamasaki, Plenum Publishing Co., New York, pp. 565574.

L e v y M., Z e h a vi U., N a i m M., P o l a c h e c k I., 1986. An improved procedure for the isolation of medicagenic acid $3 O \beta \mathrm{D}$ glucopyranoside from alfalfa roots and its antifun gal activity on plant pathogens. J. Agric. Food Chem. 34: 960965.

M a r t y n i u k S., B i a 1 y Z., J u r z y s t a M., 2002. Inhibitory effect of Medicago arabica and Medicago murex constituents on the growth and pathogenicity of Gaeumannomyces graminis var. tritici. In: Modern fungicides and antifungal compounds, ed.: H W. Dehne, U. Gisi, K.H. Kuck, P.E. Russell, H. Lyr, AgroConcept GmbH, Bonn, pp. 395400.

Mart y n i u k S., J u r z y s t a M., 2005. Aktywność antygrzybowa (Gaeumannomyces graminis var. Tritici) różnych glikozydów kwasu medikagenowego. Acta Agrobot. 59 (2): 7180.

Marty ni uk S., W roblew s ka B., Jurz y s t a M., B i ał y Z., 1996. Saponins as inhibitors of cereal pathogens: Gaeumannomyces graminis v. tritici and Cephalosporium grami nem. In: Modern fungicides and antifungal compounds, Eds. H. Lyr, P.E. Russel and H.D. Sisler, pp. 193 197. UK: Intercept, Andover.

O l e s z e k W., 1996. Alfalfa saponins: structure, biological activity and chemotaxonomy. In: Saponins Used in Food and Agriculture; Waller, G. R., Yamasaki, K., Eds.; Plenum Press, New York, pp. 155170. 
S a n i e w s k a A., B i a ł y Z., J u r z y s t a M., 2003. The effect of alfalfa (Medicago sativa) saponins on Botrytis tulipae and Phoma narcissi growth. Phytopathol. Pol. 27: 1527.

S a n i e w s k a A., J a r e c k a A., B i a $\nmid$ y Z., J u r z y s t a M., 2005. Antifungal activity of saponins from Medicago arabica L. shoots against some pathogens. Allelopathy J. 16 (1): 105112.

S a n i e w sk a A., J u r z y s t a M., B i a ł y Z., 2001. Differential antifungal activity of alfalfa (Medicago sativa $\mathrm{L}$.) saponins originated from roots and aerial parts for some ornamental plant pathogens. Acta Agrobot. 54 (1): 3143.

S z c z e p a n i k M., B i a ł y Z., J u r z y s t a M., 2004). The insecticidal activity of saponins from various Medicago spp. against Colorado potato beetle, Leptinotarsa decemlineata Say. Allelopathy J. 14 (2): 177186.

T a v a A., M e 11 a M., A va to P., Argent i eri M. P., B i a ł y Z., J u r z y st a M. 2005. Triterpenoid glycosides from leaves of Medicago arborea L. J. Agric. Food Chem. 53: 99549965.

\section{Aktywność antygrzybowa saponin korzeni Medicago hybrida w stosunku do kilku patogenów roślin ozdobnych}

\section{Streszczenie}

Oszacowano in vitro aktywność sumy saponin pozyskanych z korzeni Medicago hybrida na wzrost grzybni sześciu patogenów i przetestowano osiem dominujących glikozydów saponinowych względem Botrytis cinerea. Suma saponin wykazała fungistatyczny wpływ przy wszystkich badanych stężeniach $(0,01 \%, 0,05 \%$ i $0,1 \%)$ ale ich aktywność była różna dla poszczególnych grzybów. Najwyższe stężenie $(0.1 \%)$ saponin było najbardziej efektywne i wyrażało się silnym hamowaniem Fusarium oxysporum f. sp. callistephi (84,4\%), Botrytis cinerea (69,9\%), Botrytis tulipae (68,6\%), Phoma narcissi (57,2\%), Fusarium oxysporum f. sp. narcissi (55,0\%). Podczas, gdy Fusarium oxysporum Schlecht, patogen pochodzący z Muscari armeniacum był zahamowany zaledwie w 9,5\%. Osiem dominujących glikozydów saponinowych wyodrębnionych z sumy saponin testowano w stosunku do Botrytis tulipae. Wzrost liniowy grzybni tego patogena był silnie zahamowany przez dwa glikozydy: $3-O-\beta$-Dglukopyranozyd hederageniny i 3-O- $\beta$-D-glukopyranozyd kwasu medikagenowego. 3 - $O$ - $\beta$-D-glukuronopyranozylo-28- $O$ - $\beta$-D-glukopyranozyd kwasu medikagenowego i 3- $O$-[ $\beta$-D-glukuronopyranozylo $(1 \rightarrow 2)$ - $\alpha$-L-galaktopyranozylo]-28- $O$ - $\beta$-D-glukopyranozyd kwasu oleanolowego wykazywały niską fungitoksyczność. 3- $O$ - $\beta$-D-glukopyranozylo-28- $O$ - $\beta$-D-glukopyranozyd kwasu medikagenowego, 3- $O$-[ $\alpha$-L-rhamnopyranozylo $(1 \rightarrow 2)$ - $\beta$-D-glukopyranozylo $(1 \rightarrow 2)$ - $\beta$-D-glukopyranozylo]-28- $O$ - $\beta$-Dglukopyranozyd hederageniny i $3-O$ - $\beta$-D-glukuronopyranozylo- $28-O$ - $\beta$-D-glukopyranozyd hederageniny nie wpływają lub tylko śladowo wpływają na wzrost badanego patogena. Podczas, gdy $2 \beta, 3 \beta$-dihydroxyolean-12ene-23-al-28-karboksy $3-O$ - $\beta$-Dglukuronopyranozylo- $28-O-\beta$-D-glukopyranozyd lekko stymuluje wzrost $B$. tulipae. 